\title{
Rocky Shore Biotic Assemblages of the Maltese Islands (Central Mediterranean): A Conservation Perspective
}

\author{
Patrick J. Schembri, Alan Deidun, Adrian Mallia, and Lucienne Mercieca \\ $\dagger$ Department of Biology \\ University of Malta \\ Msida MSD06, Malta \\ patrick.j.schembri@um.edu.mt
}

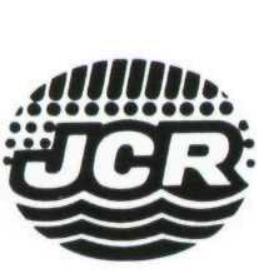

\begin{abstract}
SCHEMBRI, P.J.; DEIDUN, A.; MALLIA, A., and MERCIECA, L., 2005. Rocky shore biotic assemblages of the Maltese Islands (central Mediterranean): a conservation perspective. Journal of Coastal Research, 21(1), 157-166. West Palm Beach (Florida), ISSN 0749-0208.

Limestone rocky shores constitute ca $90.5 \%$ of the $272 \mathrm{~km}$ coastline of the Maltese islands. Only some $40 \%$ of this rocky coastline is gently sloping and easily accessible. Such shores are heavily impacted with $96 \%$ of the accessible coastline dominated by tourist-related or by maritime activities. We characterised the biotic assemblages of lowland Maltese rocky shores and tested the popularly held view that given the scarce variation in physical characteristics, such shores form a homogenous habitat.

Belt transects were laid perpendicular to the shoreline from biological zero to the adlittoral zone on seven Coralline Limestone and one Globigerina Limestone shores. Cover (for algae and encrusting species) or population density (for animals except sponges) were estimated using $0.5 \mathrm{~m} \mathrm{X} 0.05 \mathrm{~m}$ quadrats placed contiguously for the first few metres and then at regularly spaced intervals.

Overall, 19 faunal and 47 floral species, and 10 faunal and 8 floral species were recorded from the Coralline and Globigerina transects respectively, with $60.8 \%$ faunal and $25.6 \%$ floral species common to the two substrata. Hierarchical clustering showed that the Coralline and Globigerina transects harboured distinct biotic assemblages and identified an upper shore assemblage dominated by the littorinid Melarhaphe neritoides and barnacles, and a lower shore assemblage dominated by algae and molluses; a mid-shore transition zone where certain species from both assemblages reached peaks of abundance was present in almost all Coralline and the majority of Globigerina transects. Differences in biota between the two types of shore are most likely primarily related to differences in microtopography and, to a lesser degree, to exposure.

It is concluded that in spite of gross physical similarity, Maltese lowland rocky shores are biotically inhomogeneous, making conservation of individual sites much more important than previously thought.
\end{abstract}

ADDITIONAL INDEX WORDS: Limestone shores, Globigerina Limestone, Coralline Limestone, fauna, flora, zonation, exposure, microtopography.

\section{INTRODUCTION}

With a total surface area of just $316 \mathrm{~km}^{2}$, the Maltese Islands are among the smallest islands in the Mediterranean, however, they also have one of the highest population densities in the world (1194 individuals $/ \mathrm{km}^{2}$ ) and the local population is further inflated by over 1.2 million tourist arrivals each year (Mallia et al., 2002). Nonetheless, in spite of their limited size and the high human impact, the Maltese Islands exhibit an interesting array of coastal habitats, some of which possess unique species or features (ANDERSON and SCHEMBRI, 1989; AXIAK et al., 1998). Rocky shores are the most widespread coastal habitat, constituting ca. $90.5 \%$ of the $272 \mathrm{~km}$ coastline of the islands, as opposed to the $2.4 \%$ constituted by 'soft sediment' shores. Some $7 \%$ of the coastline is built-up.

Over $60 \%$ of the coastline of the Maltese Islands is inaccessible due to both natural and anthropogenic factors (ANDERSON and SCHEMBRI, 1989). The remaining stretches of accessible coastline therefore come under intense pressure from

03-0043R received 11 May 2003; accepted in revision 03 December 2003. development, especially from the vitally important tourist industry. Thus, almost $82.0 \%$ of the accessible coastline is dominated by tourist-industry related development and another $14.0 \%$ is occupied by maritime activities (AXIAK et al., 1998). Therefore, conservation of coastal habitats must compete with these economic considerations.

While, in considering applications for coastal development, the conservation of other types of coastal habitats is rightly given importance, the tendency has been to regard Maltese rocky shores as less in need of conservation since they occupy a comparatively large area and they appear to be much the same everywhere. This attitude is fuelled by the surprising lack of scientific study that Maltese rocky shore biotic assemblages have received. Practically the only published works on the ecology of Maltese rocky shore biota are the studies of RICHARDS (1983) on the zonation of molluscs on Maltese rocky shores and whose main finding was that the composition of the fauna varied with exposure; that of MALLIA and SCHEMBRI (1995) on the use of rocky shore biotic assemblages as indicators of organic enrichment; and that of AzZOPARDI and SCHEMBRI (1997), who studied vermetid crusts. 
In order to address this lack of information, we have made a qualitative and quantitative study of the biotic assemblages of representative gently sloping rocky shores on the three main islands of the Maltese archipelago. Our aim was to characterise these assemblages and to assess their conservation importance, particularly by testing the popularly held view that, locally, the rocky shore habitat is homogeneous.

It is well known that on a large spatial scale, differences between littoral rocky shore assemblages are a result of such factors as exposure to wave action, the nature of the substratum and its topography, influence of sunlight and shade, climatic conditions, biological interactions, salinity and the concentration of nutrient salts, and tidal cycles; however, differences at much smaller scales are also possible if some of these factors vary significantly between different shores or sections of the same shore (LEwIS, 1964; MoORE and SEED, 1985; LIT. TLE and KITCHING, 1996; RAFFAelli and HaWkINS, 1996).

The Maltese Islands are composed of carbonate rock, mainly limestones, and are tilted towards the NE, producing a submerged and generally lowland northern coastline and an emerged and almost exclusively cliff-dominated southern coastline. Depending mainly upon the type of limestone but also to an extent upon the dip of the rock, the northern lowland coastline displays considerable variations. Therefore, $a$ priori, a difference in exposure to wave action, substratum geology and topography between different Maltese lowland shores is expected to result in some variation in the biotic assemblages present. Other aims of this work were to quantify such differences between shores and to identify the predominant biotic assemblages.

\section{MATERIALS AND METHODS}

Suitable accessible stretches of the lowland coastline from the three main islands of the Maltese archipelago (Malta, Gozo and Comino) were studied (Figure 1). All the shores were situated on the northeastern coast of the islands except for a site located on the southern coast of the island of Comino and for Ghar Lapsi, which is one of the very few lowland shores on the southern coastline of the island of Malta. The rock at White Rocks was Globigerina Limestone, that at Qawra, Bahar ic-Caghaq and Hondoq ir-Rummien (Gozo) was Lower Coralline Limestone, while that at Mistra, Dahlet ixXmajjar, Ghar Lapsi and Comino was Upper Coralline Limestone. Globigerina Limestone is a foraminiferal biomicrite, Lower Coralline Limestone is a dense, semi-crystalline biosparite, while Upper Coralline Limestone is a coarse biosparite (PEDLEy et al., 1978). Practically all Maltese rocky shores are made of one or other of these rock types (OIL ExPLORATION DiRECTORATE, 1993). Globigerina Limestone shores generally have a smooth topography while Coralline rock is invariably rough and pitted.

The fauna and flora of the shores studied were assessed quantitatively by means of continuous belt transects laid perpendicular to the shoreline (BAKER and CROTHERS, 1987). Transects were laid from the biological zero point for Coralline shores and from $0.25 \mathrm{~m}$ below biological zero for the Globigerina shore, to the beginning of the adlittoral zone. 'Biological zero' was taken as the point where the first stands of

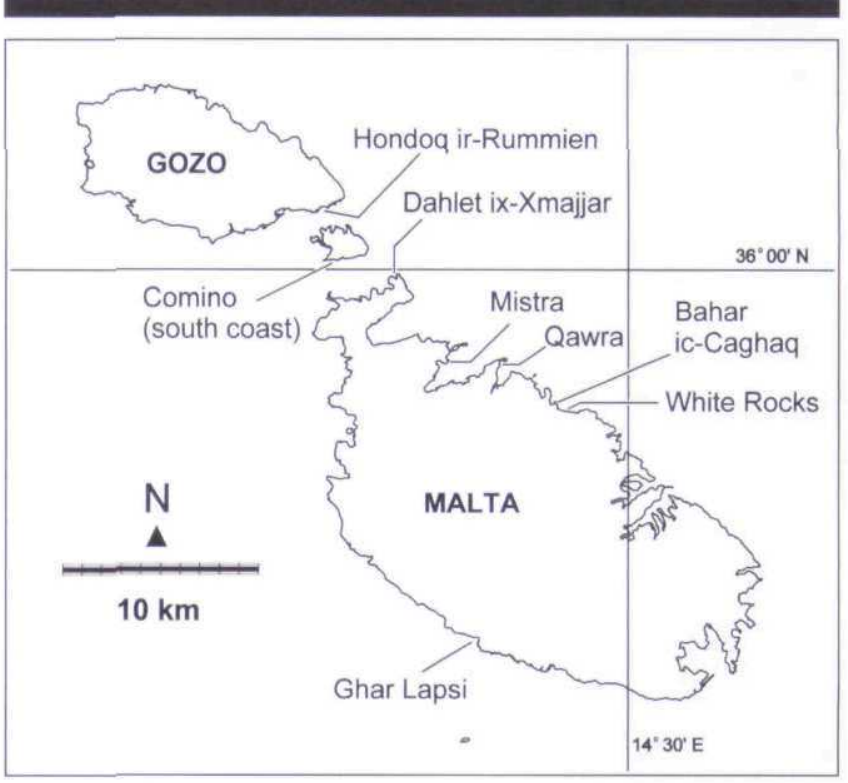

Figure 1. Map of the Maltese Islands showing the location of the shores studied.

the phaeophycean Cystoseira spp. occurred (BOUDOURESQUE and CinelLI, 1976). On the microtidal Maltese shores (maximum tidal range $=0.26 \mathrm{~m}$; DraGo and XUEREB, 1993) where chart datum is very difficult to establish by surveying, MALLIA and SCHEMBRI (1996) have shown that 'biological zero' can be used to determine 'mean sea level' with an acceptable degree of accuracy for ecological work (biological zero is ca 23.5 $\mathrm{cm} \pm 1 \mathrm{~cm}$ above chart datum). The supralittoral/adlittoral boundary was taken as the point of first occurrence of the terrestrial maritime shrub Inula crithmoides.

One transect was laid on each of the Coralline shores, however 15 transects were laid on the extensive stretch of Globigerina shore at White Rocks.

A $0.5 \mathrm{~m} \times 0.05 \mathrm{~m}$ wire frame was used as a quadrat for sampling. This shape of quadrat was necessitated by the very compressed zonation. The quadrat was moved along a measuring tape that was taken to be the midline of the short axis of the belt transect. Quadrats were taken contiguously for the first few metres since here changes in the nature of the assemblages present occur over very small spatial scales, but once variation became less marked, quadrats were laid at regularly spaced intervals.

All animal species, except sponges, were recorded as number of individuals and the data were later standardized to abundance per metre squared. Sponges, lichens and all algal species were recorded as percentage cover by using gridded sighting frames overlaid on the quadrat. Mean abundances and mean percentage cover values were calculated using only the quadrats in which the particular organism was recorded. Sampling was carried out between the months of July and September to minimise variations due to seasonal changes in climate and sea conditions.

The profile of each transect was determined using the 'stepping' technique described by MALING (1989). The exposure of 
Table 1. Physical characteristics of the seven Coralline Limestone shores and the single Globigerina Limestone shore studied. One transect was laid on each Coralline shore and 15 transects on the Globigerina shore, hence for the latter, the range of values is given.

\begin{tabular}{lccccc}
\hline \hline \multicolumn{1}{c}{ Location } & $\begin{array}{c}\text { Rock } \\
\text { type }{ }^{(1)}\end{array}$ & $\begin{array}{c}\text { Thomas } \\
\text { Exposure } \\
\text { Index }\end{array}$ & $\begin{array}{c}\text { Aspect } \\
\text { Mean Slope } \\
\text { (degrees) }\end{array}$ & $\begin{array}{c}\text { Transect } \\
\text { length } \\
\text { (metres) }\end{array}$ \\
\hline Qawra & LCL & 2.61 & NE & 14.1 & 10.1 \\
Bahar ic-Caghaq & LCL & 3.89 & NE & 15.7 & 11.3 \\
Mistra & UCL & 5.49 & NE & 18.2 & 21.6 \\
Dahlet ix-Xmajjar & UCL & 6.10 & NE & 14.3 & 23.2 \\
Hondoq ir-Rummien & LCL & 6.59 & S & 18.0 & 18.3 \\
Comino (south coast) & UCL & 9.23 & S & 14.4 & 22.9 \\
Ghar Lapsi & UCL & 12.85 & SW & 21.0 & 40.0 \\
White Rocks & GL & $4.81-8.46$ & NE & $5.0-21.0$ & $8.7-16.2$ \\
\hline
\end{tabular}

(1) UCL $=$ Upper Coralline Limestone; $\mathrm{LCL}=$ Lower Coralline Limestone; $\mathrm{GL}=$ Globigerina Limestone

each shore was estimated using the physically-derived exposure index proposed by THOMAS (1986).

In view of the great difficulty in distinguishing between specimens of Chthamalus montagui and Chthamalus stellatus in the field, especially when dealing with juveniles, these two species were recorded as Chthamalus spp.

Data were analysed statistically by NMDS and agglomerative group average linkage, hierarchical clustering on a similarity matrix generated using the Bray-Curtis or Jaccard similarity measures, employing the PRIMER 5 statistical package (CLARKE and WARWICK, 1994). All faunal results were $\log$ transformed so as to minimize the distortion produced by a few very abundant species (Melarhaphe neritoides and Chthamalus spp).

In order to identify any existing zonation patterns on the rocky shores sampled, presence/absence of flora and fauna in the transects were analysed separately by cluster analysis for Globigerina and Coralline Limestone shores, also separately. In identifying the main assemblages, any quadrats that did not fall within the main clusters were noted, as was the presence of quadrats that were completely devoid of any biota. In order to simplify the interpretation of zonation patterns, species present in less than $1 \%$ of the total number of quadrats sampled on each type of shoreline were removed from the analyses. This resulted in 6 faunal species (Cardita calyculata, Columbella rustica, Calcinus tubularis, Anemonia viridis, Ocinebrina cf. edwardsii and Fissurella nubecula) and 16 floral species (Acetabularia acetabulum, Corallina elongata, Symploca hydroides, Cladophora sericea, Dichotrix spp., Placoma vesiculosa, Dilophus fasciola, Acetabularia parvula, Anadyomene stellata, Pneophyllum cf. limitatum, Herposiphonia secunda, Alsidium cf. corallinum, Valonia utricularis, Sphacelaria tribuloides, Acanthophora najadiformis and Hydrocoleus cf. lyngbyiaceum) not being considered for the Coralline shores whilst none of the floral and faunal species recorded from the Globigerina shore were removed from the analyses.

\section{RESULTS}

Physical data for the shores studied are presented in Table 1 , while Table 2 gives a list of the species recorded.

A total of 19 and 10 faunal species were recorded from the
Table 2. Classified list of species recorded from the shores studied.

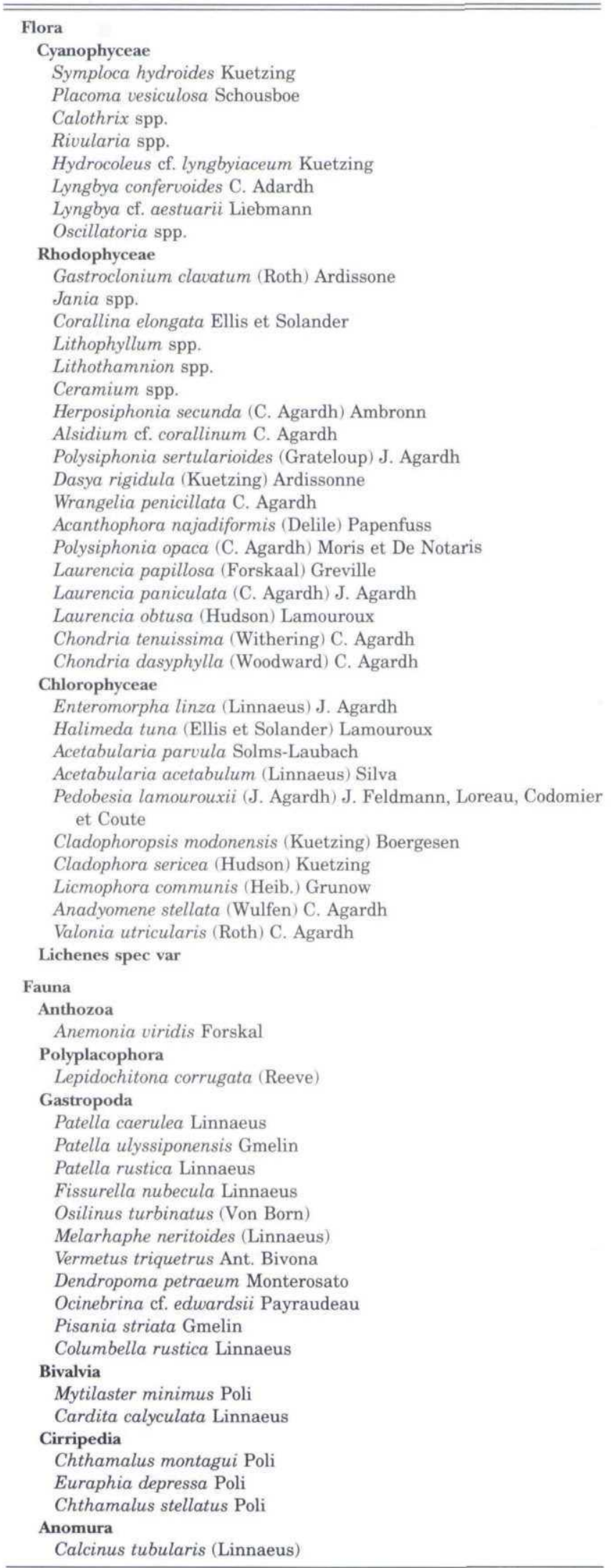


Coralline and Globigerina shores respectively, whilst 47 and 8 floral species were recorded respectively from the two types of shores. For the individual Globigerina transects, species richness ranged from 3 to 6 for flora and from 9 to 10 for fauna. The corresponding figures for the individual Coralline sites were 11 to 22 and 10 to 17 . Seventeen faunal $(60.8 \%$ of total faunal species) and 23 floral (25.6\% of total floral species) species were common to the two types of substratum.

The most widespread floral species on the Globigerina shore were Lithophyllum spp. (mean percentage cover = $31.9 \%)$, Polysiphonia opaca (mean percentage cover $=14.6 \%$ ) and Laurencia papillosa (mean percentage cover $=19.0 \%$ ). The most widespread fauna on the Globigerina shore were vermetids (mean density $=3618.0$ individuals $/ \mathrm{m}^{2}$ and constituting $47.8 \%$ of the total faunal individuals recorded), $\mathrm{Me}$ larhaphe neritoides (mean density $=438.1$ individuals $/ \mathrm{m}^{2}$ and constituting $19.9 \%$ of the total faunal individuals recorded) and Chthamalus spp. (mean density $=206.0$ individuals/ $\mathrm{m}^{2}$ and constituting $10.5 \%$ of the total faunal individuals recorded).

For the Coralline shores the most widespread flora were Polysiphonia opaca (mean percentage cover $=23.1 \%$ ), lichens (mean percentage cover $=8.6 \%$ ) and 'encrusting corallines' (mean percentage cover $=12.5 \%$ ). Encrusting coralline algae and the rhodophyte Ceramium spp. occurred in all the Coralline transects. On the Coralline shores, Lepidochitona corrugata, Melarhaphe neritoides, Osilinus turbinatus and Chthamalus spp. were found in all locations sampled. The most abundant animals on these shores were the vermetid Dendropoma petraeum (mean density $=2305.1$ individuals $/$ $\mathrm{m}^{2}$ and constituting $38.9 \%$ of the total faunal individuals recorded), Chthamalus spp. (mean density $=310.1$ individuals/ $\mathrm{m}^{2}$ and constituting $26.6 \%$ of the total faunal individuals recorded) and Melarhaphe neritoides (mean density $=698.7$ individuals $/ \mathrm{m}^{2}$ and constituting $26.2 \%$ of the total faunal individuals recorded).

In an attempt to distinguish discrete biotic assemblages on the shores studied, quadrats in each transect for the Globigerina and Coralline shores were classified by cluster analysis, treating floral and faunal data separately. Cluster analysis classified quadrats along each transect into either two or three groups/zones and the results of these analyses are summarised in Figures 2 and 3.

In transects exhibiting three zones, the boundary between the lower shore zone and the middle shore zone ranged from $-0.2 \mathrm{~m}$ to $+0.4 \mathrm{~m}$ from biological zero for flora and from +0.3 $\mathrm{m}$ to $+1.9 \mathrm{~m}$ for fauna, with the average distance being $0.1 \mathrm{~m}$ and $0.9 \mathrm{~m}$ for flora and fauna respectively. The boundary between the middle shore zone and the upper shore zone ranged from $0.1 \mathrm{~m}$ to $1.8 \mathrm{~m}$ and from $0.8 \mathrm{~m}$ to $2.8 \mathrm{~m}$ from biological zero for flora and fauna respectively, with the average distance being $0.8 \mathrm{~m}$ and $1.7 \mathrm{~m}$, respectively. In transects with two zones, the boundary between the lower and upper zones ranged from $0.7 \mathrm{~m}$ to $1.4 \mathrm{~m}$ and from $1.0 \mathrm{~m}$ to $1.3 \mathrm{~m}$ from biological zero for flora and fauna respectively, with the average distance being $1.0 \mathrm{~m}$ and $1.2 \mathrm{~m}$, respectively.

The number of quadrats that fell outside the main clusters identified comprised $1.7 \%$ and $3.3 \%$ of all quadrats for the Globigerina Limestone floral and faunal analyses respective- ly (Figure 2), with an average respective distribution of 2.3 quadrats and 4.3 quadrats per transect. For the Coralline shores, the number of quadrats that fell outside the main clusters resulting from the analyses comprised $2.4 \%$ and $7.3 \%$ of all quadrats for flora and fauna respectively (Figure 3), with an average respective distribution of 1.3 quadrats and 8.4 quadrats per transect.

For 'three-zone' transects on the Globigerina shore, the lower shore floral zone was mainly characterised by Jania spp., Cladophora spp., Laurencia papillosa and Lithophyllum spp., whilst the middle shore zone was characterised by the same species and additional ones, such as Acetabularia parvula and Anadyomene stellata. The upper shore zone was characterised only by Lithophyllum spp. and Rivularia spp.

The major species characterising the lower shore faunal zone in the 'three-zone' Globigerina transects were vermetids, patellids, the chiton Lepidochitona corrugata and the bivalve Mytilaster minimus; the middle shore zone was dominated by barnacles (Chthamalus spp.) and by Osilinus turbinatus, whilst the upper shore zone was characterised by Melarhaphe neritoides which was the sole species present.

The floral and faunal species characterising the middle zone of the 'three-zone' Globigerina transects are also present in the 'two-zone' transects but without forming a distinct group between the lower and upper shore zones.

On the Coralline shores, six of the seven transects gave three zones for flora, while all seven gave three zones for fauna. The only 'two-zone' Coralline transect was that for $\mathrm{Ba}$ har ic-Caghaq flora, where the boundary between the lower and the upper shore zones occurred $0.6 \mathrm{~m}$ above biological zero.

With respect to flora, only coralline algae and Ceramium spp. occurred in all seven Coralline transects, all of which had different wave exposure regimes. Dasya rigidula, Lyngbya aestuarii, Sphacelaria tribuloides and Dilophus fasciola were only recorded from the high exposure sites (Thomas Index >9.23; Table 1); Acetabularia acetabulum, Enteromorpha linza, Licmophora communis, Gastroclonium clavatum, Symploca hydroides, Cladophoropsis modonensis, Pedobesia lamourouxii and Dichothrix spp. were restricted to low exposure sites (Thomas Index $<3.86$; Table 1); the largest number of flora species occurred at sites with medium exposure (Thomas Index 3.86-9.23; Table 1); such species included Pneophyllum cf. limitatum, Dilophus repens, Hydrocoleus cf. lyngbyiaceum and Lyngbya confervoides.

For fauna, only Lepidochitona corrugata, Patella ulyssiponensis, Patella caerulea, Patella rustica, Vermetus triquetrus, Dendropoma petraeum, Melarhaphe neritoides and Chthamalus spp. were recorded from all seven locations. Although Euraphia depressa was found in six locations, it displayed its maximum abundance at the most exposed site, Ghar Lapsi, with a density of 7000 individuals $/ \mathrm{m}^{2}$, in contrast to the most sheltered site, Qawra, where only three individuals were encountered in the whole transect.

On the Coralline shores, the majority of algae were located in the lower shore zone, together with the molluscs Patella ulyssiponensis, Patella caerulea, Lepidochitona corrugata, Osilinus turbinatus, Dendropoma petraeum and small individuals of Chthamalus spp. Other floral species, more tolerant 

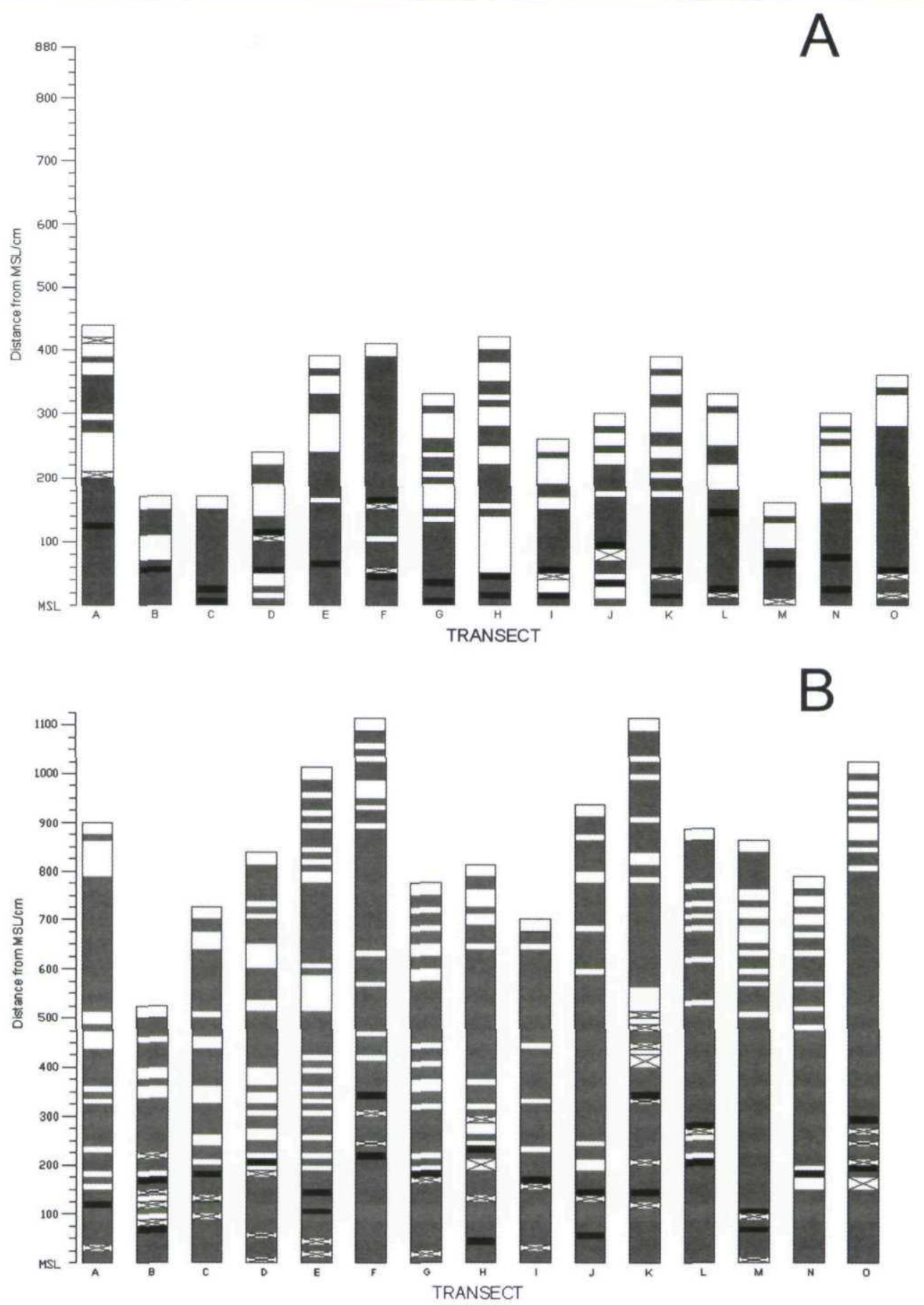

Figure 2. Graphical presentation of the results of cluster analysis (agglomerative, group average linkage; Bray-Curtis similarity measure) for (A) the floral data and (B) the faunal data for each Globigerina transect at White Rocks (labelled A to O). Each vertical bar represents a transect consisting of contiguous quadrats of height $5 \mathrm{~cm}$ laid from mean sea level (MSL) to the first occurrence of terrestrial vegetation. Cluster analysis generally grouped quadrats into a lower shore, a middle shore and an upper shore group and for each transect, the boundaries between these groups are marked by the black bars [ ] . Note that the middle shore group is absent in some transects, and for these, there is only one black bar which represents the boundary between the lower and the upper shore groups of quadrats. A few individual quadrats were not grouped by the cluster analysis with the rest of the quadrats of their shore zone, and these quadrats are indicated by crosses [区]. Quadrats without biota, which were excluded from the analyses, are shown as empty $[\square]$. Only the first few empty quadrats at the top of each transect are shown, however each transect has a longer bare zone until the start of terrestrial vegetation (transect length is given in Table 1). 


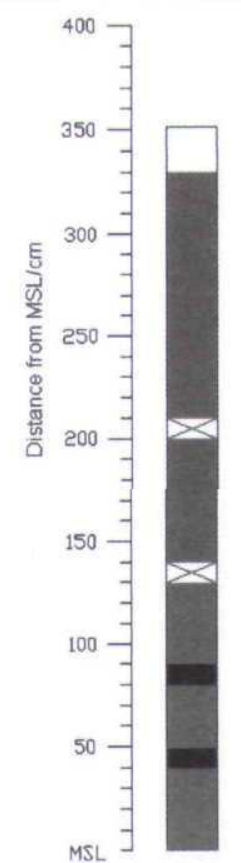

LPS

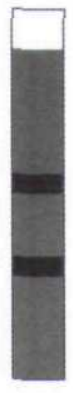

CMO
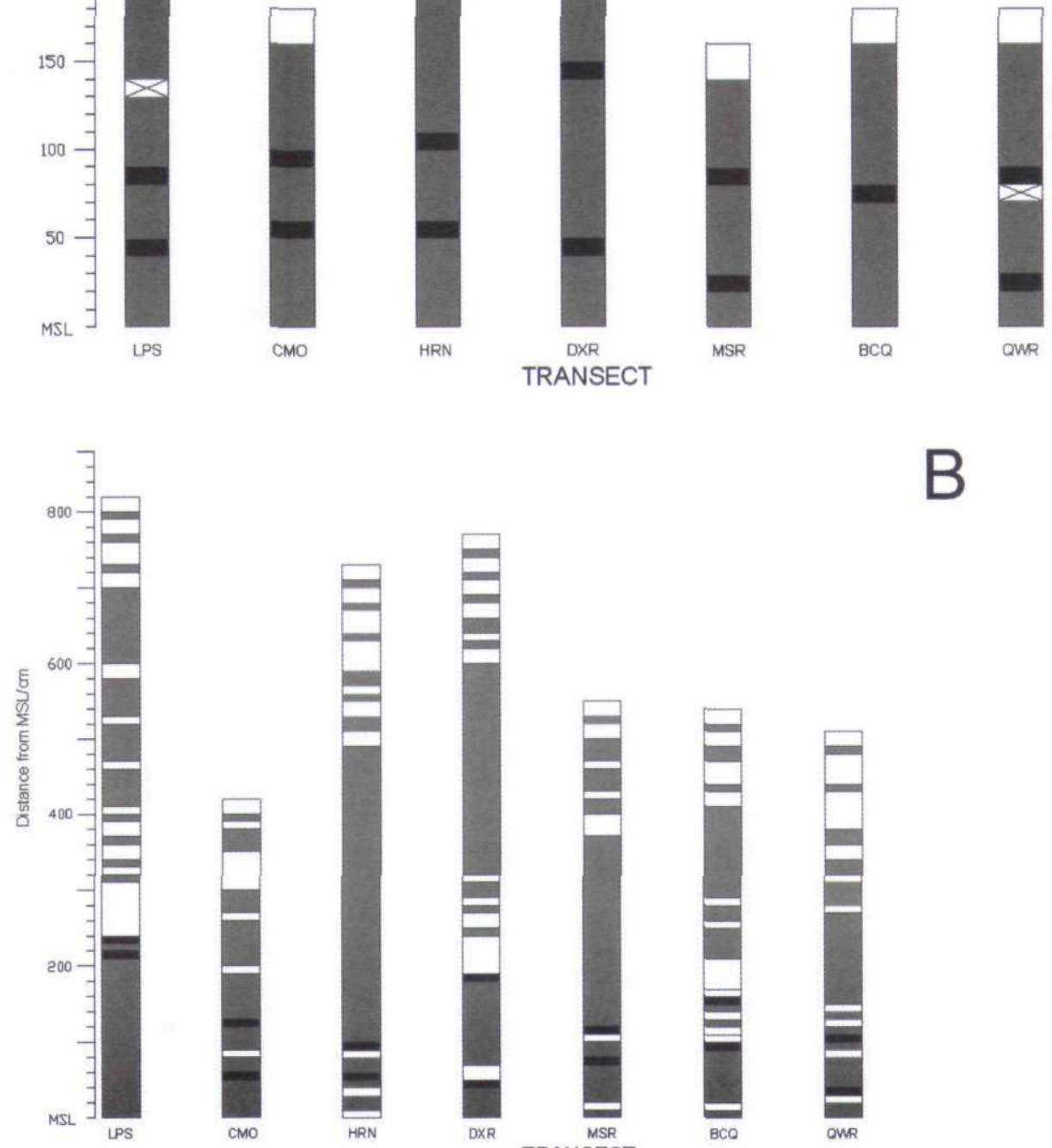

MSR

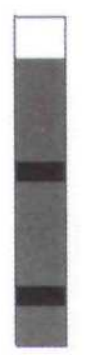

DXR

TRANSECT

A

BCQ OWR

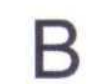

Figure 3. Graphical presentation of the results of cluster analysis (agglomerative, group average linkage; Bray-Curtis similarity measure) for (A) the floral data and (B) the faunal data for each Coralline transect (Key: LPS Ghar Lapsi, CMO Comino, HRN Hondoq ir-Rummien, DXR Dahlet ix-Xmajjar, MSR Mistra, BCQ Bahar ic-Caghaq, QWR Qawra). Conventions used as for Figure 2.

of desiccation, such as Rivularia atra, Lyngbya confervoides, Polysiphonia opaca, Oscillatoria cf. limosa, Cladophora spp., Calothrix spp. and lichens, were found higher up in the same lower shore zone. Also within this zone, a distinct narrow faunal zone could be distinguished, mainly characterised by the vermetid mollusc Vermetus triquetrus. The upper part of this lower shore zone was inhabited mainly by adult individuals of Chthamalus spp., together with Patella rustica and occasionally also Osilinus turbinatus and Dendropoma petraeum. 

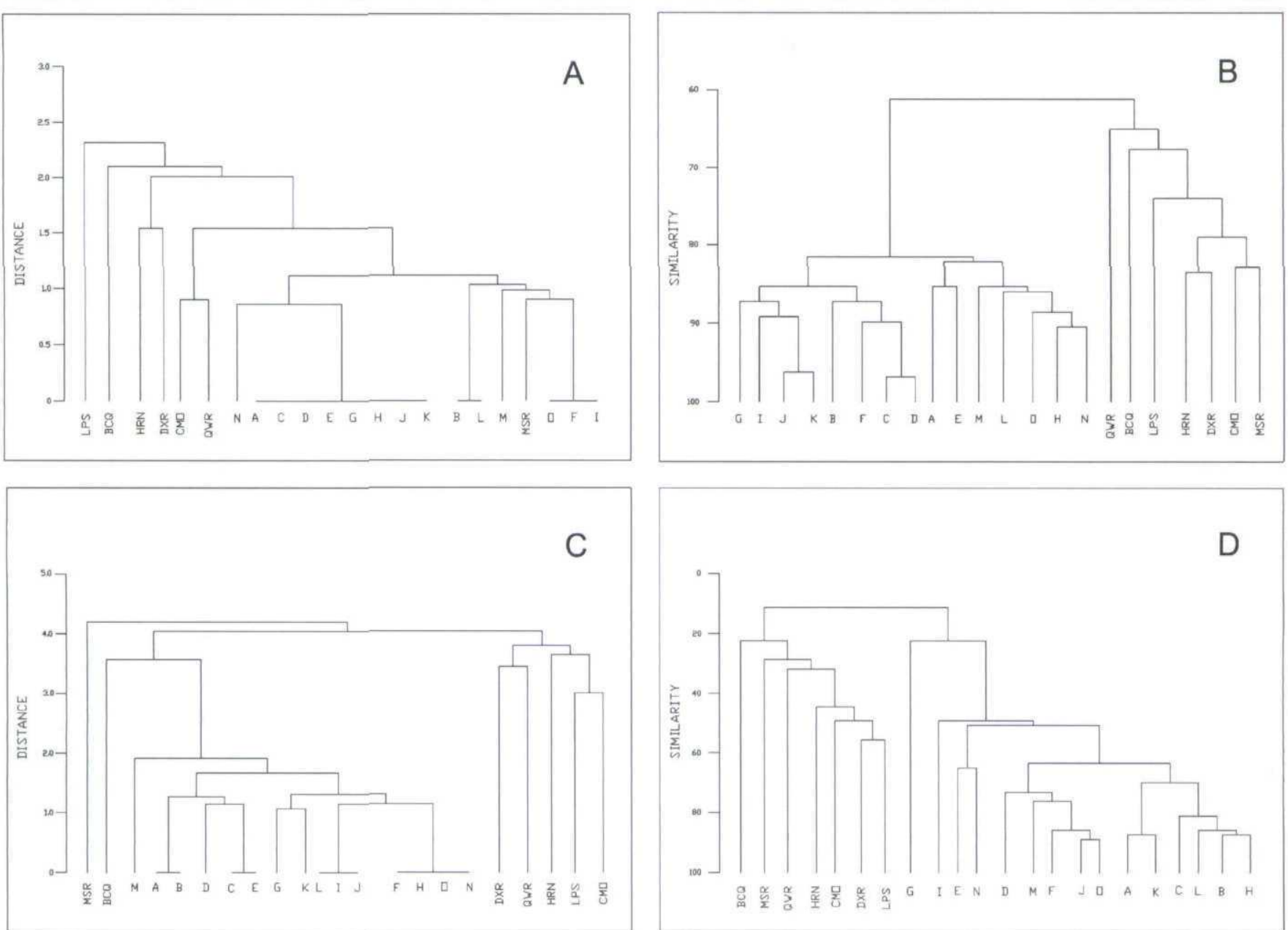

Figure 4. Dendrograms resulting from agglomerative, group average linkage, hierarchical clustering of all transects based on (A, B) fauna and (C,D) flora. Dendrograms A and C are based on presence/absence data (similarity matrix generated using the Jaccard coefficient) and dendrograms B and D are based on abundance data (similarity matrix generated using the Bray-Curtis coefficient). Data for fauna were log transformed. The Globigerina transects at White Rocks are labelled A to O, while the Coralline transects are labelled as follows: LPS Ghar Lapsi, CMO Comino, HRN Hondoq irRummien, DXR Dahlet ix-Xmajjar, MSR Mistra, BCQ Bahar ic-Caghaq, QWR Qawra.

Although the middle zone of the 'three-zone' Coralline transects was colonised by essentially the same faunal species as the two adjacent zones, with some additions (for example, Anemonia viridis), it was characterised mainly by the high abundance of certain species. In particular, Patella spp. and Chthamalus spp. reached their highest abundance within this zone, as also did the algae Jania spp. and Ceramium spp.

Based on the fauna, the upper shore zone of the Coralline shores can be divided into two parts: a lower region with the gastropod Melarhaphe neritoides, the isopod Ligia italica and occasionally the barnacle Euraphia depressa, and an upper region devoid of any macroscopic animal life, extending from the point of last occurrence of Melarhaphe neritoides up to the point of first occurrence of the terrestrial shrub Inula crithmoides.

On all the Coralline shores sampled, the length of the transects (i.e. from biological zero to the first terrestrial vegetation) generally increased with an increase in exposure to wave action (Table 1). Thus, Ghar Lapsi and Qawra have the highest and lowest exposures (Thomas Index 12.81 and 2.61 respectively); these two locations also exhibited the longest and shortest transect lengths $(40.0 \mathrm{~m}$ and $10.1 \mathrm{~m}$ respectively) (Table 1).

Hierarchical clustering (using the Jaccard and Bray-Curtis indices) indicated that Coralline Limestone and Globigerina Limestone shores harboured distinct faunal and floral assemblages from each other (Figure 4). In addition, this analysis also identified four distinct groups for the Globigerina transects, whilst no such distinct groups were identified for the Coralline transects (Figure 4).

\section{DISCUSSION}

Differences in the biotic assemblages between Globigerina and Coralline Limestone shores in the Maltese Islands do not appear to be related to differences in exposure or slope as 
there was no correlation between the groupings resulting from the NMDS and cluster analyses with either of these parameters. These differences in diversity are also probably not related directly to chemical differences in the two types of substrata since both are biogenic limestones of marine sedimentary origin.

More important may be differences in microtopography. Coralline shores are much more indented and have a higher rugosity than Globigerina ones, offering more crevices for attachment of biota. This may explain the striking decrease in species diversity and population densities observed on the Globigerina Limestone shore compared to the Coralline Limestone ones. The highest decrease in density was exhibited by species that attach to the substratum. In particular, the barnacles Chthamalus spp. showed a $1193 \%$ decrease in abundance in the Globigerina transects when compared to the Coralline transects.

The absence of suitable microhabitats, coupled to a low exposure, is the probable reason for the anomalous absence of Euraphia depressa from the Coralline shore at Bahar ic-Caghaq. The relatively smooth microtopography of this shore is probably also the reason for the low population density of Melarhaphe neritoides here, where it had the second lowest abundance of all the shores studied. Littorinids preferentially occupy rock crevices and cracks (FOSTER, 1966; CHOW, 1975; GRECH and Schembri, 1989) and the frequency of these may act as a limiting factor for the development of the Melarhaphe neritoides population (EMSON and FALLER-FrITSCH, 1976; RAFFAELLI and Hughes, 1978). The importance of microtopography in determining the distribution of biota on rocky shores is well known (MCCARTER and THOMAS, 1980).

Exposure is another factor that gives a heterogeneous biota between different local rocky shores. In fact, whilst Osilinus turbinatus was completely absent from the most exposed site at Ghar Lapsi, it was present in high numbers (600 individuals $/ \mathrm{m}^{2}$ ) at the least exposed site at Qawra. On the other hand, Euraphia depressa showed a very low abundance at Qawra, where just three individuals were encountered, whilst exhibiting its maximum abundance (i.e. 7000 individuals $/ \mathrm{m}^{2}$ ) at Ghar Lapsi.

Fauna appear to be more substratum-specific than flora. This indicates that, for flora at least, the differing microtopography of the two shore types studied does not result in the complete exclusion of particular species, but may confer selective advantages to particular species which thus are present in higher densities on one type of shore relative to the other.

The shore at Mistra is anomalous in terms of the abnormally high densities of barnacles Chthamalus spp. here, where these barnacles constituted ca $84 \%$ of the total faunal individuals collected from this site (mean density of Chthamalus spp. at Mistra was $2552.9 \mathrm{ind} / \mathrm{m}^{2}$ as compared to mean densities ranging from 10.7 to $690.2 \mathrm{inds} / \mathrm{m}^{2}$ for the other Coralline shores sampled). Similarly, Mistra had abnormally high densities of Patella rustica (mean density of 50.3 inds/ $\mathrm{m}^{2}$ compared to mean densities of 3.6-24.5 inds $/ \mathrm{m}^{2}$ recorded for the other Coralline shores sampled). On the other hand, Dendropoma petraeum had abnormally low densities (mean density of 5.2 inds $/ \mathrm{m}^{2}$ at Mistra as compared to 21.7 to 65.0 inds $/ \mathrm{m}^{2}$ for the other Coralline shores). Such a pattern is typical of sites exhibiting higher wave exposure levels than found at Mistra. One possible explanation could be the heavy swash received by the shore at Mistra as a result of high levels of powerboat activity in the area, which supplements the normal wave action.

Contrary to the differences between the Coralline and Globigerina shores, those between the various Globigerina transects can be mainly explained in terms of the different exposure levels of the transects. Although the Globigerina transects were located just a few tens of metres away from each other, they exhibited a range from 4.81 to 8.46 on the Thomas exposure index scale used in the present study. The segregation of different clusters of Globigerina transects was more clear for the faunal data than for the floral data.

Globigerina and Coralline shores differ in the vertical zonation patterns they exhibit. On both types of shore, two main zones are invariably present (a low shore and a high shore zone), however, for almost all Coralline and for the majority of Globigerina transects, a usually narrow third zone (the middle shore zone) can be identified. This middle zone may be considered as transitional, especially due to the large number of species from the two adjacent zones; for example: Lithophyllum sp., Laurencia papillosa, Cladophora sp., Lepidochitona corrugata, patellids and vermetids (distribution spanning the 'lower' and 'middle' zones); Rivularia sp. (distribution spanning all three vertical zones); and Melarhaphe neritoides (distribution spanning the 'middle' and 'upper' zones). This 'middle transition zone' separates out in the analyses carried out probably due to the presence of species that are particularly abundant in it, such as Polysiphonia spp., Patella caerulea and Chthamalus spp. No species were found to be unique to this 'middle' zone.

Coralline shores showed a more uniform zonation pattern than Globigerina ones in mostly having three vertical zones; Globigerina shores have either two or three zones, even though the Globigerina transects were located quite close to each other. The upper shore zone as identified in this study corresponds to the 'littoral fringe' of LewIS (1964) or the 'supralittoral zone' of PÉRÈs and PICARD (1964), the middle shore zone corresponds to the 'eulittoral zone' of LEWIS (1964) or the 'upper mediolittoral zone' (PÉrÈs and PICARD, 1964) whilst the lower shore zone corresponds to the 'sublittoral zone' (LEWIS, 1964) or the 'lower mediolittoral zone' of PÉRÈS and PICARD (1964).

In some cases, the main zones could be divided in 'subzones', as was the case for the supralittoral zone of the Coralline shores, which could be divided into a lower subzone characterised by Melarhaphe neritoides and barnacles, a middle subzone with Melarhaphe neritoides only, and an upper subzone corresponding to the 'bare zone' described by LEWIS (1965) and JoHANNESSON (1989). Only very few quadrats did not cluster within their spatial zones.

UNDERWOOD and JERNAKOFF (1981) and UNDERWOOD and CHAPMAN (1998) found considerable seasonal differences in the distribution of shore organisms, superimposed on the tidal zonation of the biota. However, since sampling on both Globigerina and Coralline rocky shores was conducted in the same season, seasonal variability is not considered important 
in explaining differences in the biotic assemblages of the two types of shores.

Generally, all zones had a closer seaward position on Coralline shores than on Globigerina shores and this effect was more pronounced for flora than for fauna. These two observations may be related to the lower degree of surface roughness of Globigerina shores when compared to Coralline shores, which results in the effect of wave action to be felt higher up the shore due to the lack of physical barriers which dampen such wave action; additionally, since flora are more susceptible to desiccation than fauna, being less protected, they are more dependent on wetting by wave action on the functionally tideless Maltese shores.

Due to the microtides present on Maltese shores, the different zones, especially those close to the land/water interface, occupy a smaller shore-normal distance along the shore as compared to equivalent zones on tidal shores. The middle shore zone, which was the narrowest of the zones identified, was only an average $0.7 \mathrm{~m}$ and $0.5 \mathrm{~m}$ wide for Globigerina and Coralline shores, respectively. However, this zone was the most heterogeneous in terms of species composition, due to its transitional nature.

The results presented hold many implications for the conservation of Maltese rocky shores and possibly for rocky shores on other small Mediterranean islands and elsewhere. The fact that, with few exceptions, the Maltese coastline is fragmented into sections with different rock types and that these different shore types support distinct biotic assemblages implies that Maltese rocky shores are far from being biotically homogeneous. This is well illustrated by the White Rocks/Bahar ic-Caghaq transects, where the 15 Globigerina Limestone transects at White Rocks were located just a few hundred metres away from the Coralline Limestone transect at Bahar ic-Caghaq (Figure 1), but exhibited almost $50 \%$ and $80 \%$ dissimilarity in faunal and floral assemblages respectively, from the Coralline transect.

The higher diversity on Coralline shores when compared to Globigerina shores (especially in terms of floral species), and the fact that Coralline shores are more liable to exploitation as they constitute the largest fraction of accessible Maltese rocky shores, suggest that Coralline shores have a higher conservation value than Globigerina shores in the Maltese Islands.

The biota of Maltese shores is of regional biogeographical interest since the position of the islands at the centre of the Mediterranean Sea means that they display features from both the western and the eastern basins. One example is the presence of large populations of species with sub-tropical affinity, such as the vermetids Dendropoma petraeum and Vermetus triquetrus, and the pagurid Calcinus tubularis, in resemblance to eastern Mediterranean shores, whilst the distribution of Osilinus spp. on Maltese shores mirrors to a great extent that found in Marseilles in the western basin (RICHARDS, 1983). Vermetid crusts or 'trottoirs', which are common on Maltese gently sloping shores (Azzopard and SCHEMBrI, 1997), are characteristic of the central Mediterranean region and the East Basin (SAFriel, 1966). Such crusts have been listed as threatened bioconstructions in the Red Data Book for the Mediterranean (UNEP/IUCN/GIS POSIDONIE, 1990) and the main trottoir former, Dendropoma petraeum is included in Appendix II (Strictly Protected Fauna Species) of the Bern Convention and in Annex II (Endangered or Threatened Species) of the Protocol for Specially Protected Areas and Biodiversity in the Mediterranean (SPABIM Protocol of the Barcelona Convention). All these are valid reasons for conserving such shores.

Although relatively few species are found on Maltese rocky shores, these may be present in very high population densities, in some cases much higher than found on other Mediterranean shores. For example, on the rocky shores of SE Spain in the northwestern Mediterranean, BALLESTEROS and RoMERo (1988) report mean densities for Chthamalus spp., Euraphia depressa and Patella rustica of 115.8 individuals $\mathrm{m}^{2}, 27.8$ individuals $/ \mathrm{m}^{2}$ and 11.9 individuals $/ \mathrm{m}^{2}$ respectively; the mean densities found by us on Maltese rocky shores for these same species were 310.1 individuals $/ \mathrm{m}^{2}$ and 206 individuals $/ \mathrm{m}^{2}$ (for Coralline and Globigerina shores), 28.5 individuals $/ \mathrm{m}^{2}$ and 73.0 individuals $/ \mathrm{m}^{2}$, and 55.5 individuals $/ \mathrm{m}^{2}$ and 108.6 individuals $/ \mathrm{m}^{2}$ respectively. These figures are also high when compared to central Mediterranean shores. Thus ENBYAH et al., (1986) report mean densities for Chthamalus spp., Patella spp. and Melarhaphe neritoides of 28.5 individuals $/ \mathrm{m}^{2}, 24.8$ individuals $/ \mathrm{m}^{2}$ and of 47.0 individuals $/ \mathrm{m}^{2}$ respectively for Libyan rocky shores. Some flora also seem to have higher abundances on Maltese rocky shores than elsewhere in the Mediterranean. BALlesteros and Romero (1988) report mean percentage cover values of $1.12 \%$ for Lithophyllum tortuosum and of $0.01 \%$ for Cystoseira compressa on the rocky shores of SE Spain compared to mean percentage cover of $3.19 \%$ and $7.42 \%$ for the two species respectively, for Maltese rocky shores.

In conclusion we note that the Maltese coastline, which is highly inhomogeneous in terms of microtopography and exposure to wave action throughout its $271 \mathrm{~km}$ length, is correspondingly inhomogeneous in biotic assemblages, making conservation of individual sites along the Maltese rocky coast much more important than previously thought.

\section{ACKNOWLEDGMENTS}

We are thankful to the following colleagues at the University of Malta: Edwin Lanfranco for identifying algae, Prof Anton Buhagiar for help with the statistical analyses, and Carmelo Galea for preparing the figures. We benefited greatly from discussions with Prof Javier Romero and Dr Enric Ballesteros (University of Barcelona), whom we thank. This study was funded by research grants from the University of Malta, for which we are grateful.

\section{LITERATURE CITED}

Anderson, E.W. and Schembri, P.J., 1989. Coastal zone survey of the Maltese Islands report. Beltissebh, Malta: Planning Services Division, Works Department, xii + 121p. + 100 hand-drawn colour maps + 19 synoptic maps.

Axiak, V.; Gauci, V.; Mallia, A.; Mallia E.A.; Schembri, P.J., and VELLA, A.J., (eds.), 1999. State of the environment report for Malta 1998. Floriana, Malta: Environment Protection Department, Ministry for the Environment, iii $+448 p$.

Azzopard, L. and Schembri, P.J., 1997. Vermetid crusts from the 
Maltese Islands (Central Mediterranean), Marine Life 7 (1-2), 7 16.

BAKER, J.M. and Crothers, J.H., 1987. Intertidal Rock. In: BAKER, J.M. and WolfF, W.J. (eds.), Biological surveys of estuaries and coasts. Cambridge, England: Cambridge University Press, pp.157197.

BALlesteros, E. and Romero, J., 1988. Zonation patterns in tideless environments (Northwestern Mediterranean): looking for discontinuities in species distributions. Investigaciones Pesquerias, 52(4), $595-616$.

Boudouresque, C.F. and Fresi, E., 1976. Modelli di zonazione del benthos fitale in Mediterraneo. Bollettino di Pesca e Piscicultura Idrobiologica, 3(1/2),129-143.

CHоw, V., 1975. The importance of size in the intertidal distribution of Littorina scutulata (Gastropoda: Prosobranchia). The Veliger, 18(1), 69-78.

Drago, A.F. and Xuereb, A., 1993. Tide tables 1993. Grand Harbour, Malta. Malta: Malta Maritime Authority and Malta Council for Science and Technology, 46p.

EMSON, R.H. and FALLER-FritsCH, R.J., 1976. An experimental investigation into the effect of crevice availability on abundance and size-structure in a population of Littorina rudis (Maton) (Gastropoda Prosobranchia). Journal of Experimental Marine Biology and Ecology, 23, 285-297.

EnByaH, M.A.; Buisa, A.B., and Aravindan, C.M., 1986. Distribution and seasonal variations of organisms on wave exposed and sheltered stretches of rocky shores of Al-Khomes (Splaj). Bulletin of the Marine Biology Research Centre, 7, 5-25.

Foster, B.A., 1966. The effects of wave exposure and aspect on the vertical shore distribution and population composition of Melarhaphe olivieri. Tane, 12, 37-44.

GRECH, M. and SCHEMBRI, P.J., 1989. A laboratory study of the behavioural responses of Melarhaphe neritoides (Mollusca: Gastropoda) in relation to its zonation on Maltese shores (Central Mediterranean). Marine Behaviour and Physiology, 15, 123-135.

JoHANNESSON, K., 1989. The bare zone of Swedish rocky shores: why is it there? Oikos, 54, 77-86.

LEWIS, J.R., 1964. The ecology of rocky shores. London: English Universities Press, xii $+323 p$.

LEWIS, J.R., 1965. The littoral fringe on rocky coasts of southern Norway and western Sweden. Botanica Gothoburgensia, 3, 129143.

LitTLE, C. and Kitching, J.A., 1996. The biology of rocky shores. Oxford: Oxford University Press, 240p.
MALING, D.H., 1989. Measurements from maps: principles and methods of cartometry. Oxford: Pergamon Press, xxi+577p.

MALLIA, A. and SCHEMBRI, P.J., 1995. Detecting low-level sewage pollution using rocky shore communities as bio-indicators. Rapport du Congrès de la Commission Internationale pour l'Exploration Scientifique de la Mer Méditerranée, 34, 140.

Mallia, A. and Schembri, P.J., 1996. A case for biological zeros. Xjenza [Malta], 1(1), 8-9.

Mallia, A.; Briguglio, M.; Ellul, A.E., and Formosa, S., 2002. Physical background, demography, tourism, mineral resources and land-use. State of the Environment Report for Malta, 2002. Malta: Ministry for Home Affairs and the Environment, pp. 43-169.

MCCARTER, N.H. and Thomas, A.D., 1980. Patterns of animal and plant distribution on rocky shores of the South Hams (South Devon, England). Field Studies, 5, 229-258.

Moore, P.G. and Seed, R. (eds.), 1985. The ecology of rocky coasts. Essays presented to J.R. Lewis. London: Hodder \& Stoughton, $467 \mathrm{p}$.

Oil Exploration Directorate, 1993. Geological map of the Maltese Islands. Valletta, Malta: Oil Exploration Directorate, Office of the Prime Minister, scale 1:25,000, 2 sheets.

Pérés, J. M. and PiCARD, J., 1964. Nouveau manuel de binomie benthique de la mer Méditerranée. Recueil des Travaux de la Station Marine d'Endoume, 31(47), 5-137.

RafFaeldi, D.G. and Hughes, R.N., 1978. The effects of crevice size and availability on populations of Littorina rudis and Littorina neritoides. Journal of Animal Ecology, 47, 71-84.

RAFFAELLI, D.G. and HAWKINS, S.J., 1996. Intertidal ecology. London, England: Chapman and Hall, 368p.

RICHARDS, G.W., 1983. Molluscan zonation on rocky shores in Malta. Journal of Conchology, 31, 207-224

SAFrIEL, U.N., 1966. Recent vermetid formations on the Mediterranean shore of Israel. Proceedings of the Malacological Society of London, 37, 27-34.

Thomas, M.L.H., 1986. A physically derived exposure index for marine shorelines. Ophelia, 25(1), 1-13.

UNDERWOOD, A.J. and JERNAKOFF, P., 1981. Interactions between algae and grazing gastropods in the structure of a low shore algal community. Oecologia, 48, 221-233.

UNDERWOOD, A.J. and CHAPMAN, M.G., 1998. Spatial analyses of intertidal assemblages on sheltered rocky shores. Australian Journal of Ecology. 23,138-157.

UNEP/IUCN/GIS POSIDONIE, 1990. Livre rouge "Gérard Vuignier" des végetaux, peuplements et paysages menacés de Méditerranée. Mediterranean Action Plan Technical Report Series 43, 1-250. 
Copyright of Journal of Coastal Research is the property of Coastal Education Research Foundation Incorporated and its content may not be copied or emailed to multiple sites or posted to a listserv without the copyright holder's express written permission. However, users may print, download, or email articles for individual use. 